\title{
Euroscepticism and the Anglosphere: Traditions and Dilemmas in Contemporary English Nationalism
}

\author{
BEN WELLINGS' ${ }^{1}$ and HELEN BAXENDALE ${ }^{2}$ \\ ${ }^{1}$ Monash University ${ }^{2}$ Oxford University
}

\begin{abstract}
British participation in the historical process of European integration has been persistently framed as a policy dilemma of the highest order. This dilemma was itself coloured by the existence of policy traditions that oriented Britain away from Europe and towards political communities tied to a historical interpretation of British nationality. Euroscepticism is symptomatic of these traditions and dilemmas while at the same time sustaining them. But Eurosceptics face a dilemma of their own. What serious alternative do they propose? The notion of the 'Anglosphere' was adopted on the Eurosceptic right of British politics as an alternative to European integration. As a politics of disengagement by the Cameron government played out in Europe, a policy of re-engagement began with Britain's former Dominions. Here was a response to a political dilemma that not only used historical consciousness and political tradition as its point of departure, but as its place of destination too.
\end{abstract}

\section{Introduction}

As a politics of disengagement by the Cameron government emerged in Europe, a policy of re-engagement with Britain's former Dominions was also observable. Similarly, the rise in vocal Euroscepticism within the Conservative Party after 2010 was preceded by a decade of discussion about the existence of the so-called 'Anglopshere' as a viable alternative to the UK's involvement in the processes and politics of European integration. An analysis of these trends and policy shifts casts light on the continuing existence of a 'Commonwealth' and 'English-speaking Peoples' tradition in British political thought during the decades of European integration. However, it should be noted that the discontinuities are as important as the continuities. The rise of thinking about the so-called 'Anglosphere' certainly builds on the Commonwealth tradition, but it has been re-worked for a global, rather than, imperial, era. Moreover, despite the existence of a Commonwealth tradition on the left of British politics, the Anglosphere appeals to the right, and Thatcherite Eurosceptics in particular.

It is argued in this article that the idea of the Anglosphere has been advanced by Eurosceptics in response to criticisms about the lack of an alternative vision to European integration. Importantly, these responses to the British dilemma about Europe reinforce the centrality of British national narratives set in opposition to European integration at the heart of an increasingly Eurosceptic Englishness. The Anglosphere therefore represents a response to a political dilemma that not only uses historical consciousness and political tradition as its point of analytical departure, but one that views history and tradition as its place of destination too. 
In order to explain the rise of such thinking among British Eurosceptics this article adopts a four-part structure. The first part examines traditions and dilemmas in relation to Britain, Europe and the English-speaking peoples in the context of an emerging English Euroscepticism. The second part analyzes understandings of European integration in historical narratives of the Anglo-British past. The third part highlights the links between Euroscepticism and the Anglosphere. Finally, the fourth part returns to the overlaps between the Anglosphere and British political traditions.

\section{Britain, Europe and the English-Speaking Peoples: Traditions and Dilemmas}

Speaking in late in 2011 about his nation's forthcoming accession to the EU, Branko Baricevic, Croatian ambassador in Brussels, stated that 'the EU for us is not a question of choice. It is our destiny. Like it or not, this is not a choice' (cited in Vaudin d'Imecourt, 2011, p. 8). This statement from a state official of a country emerging from market socialism, civil war and authoritarianism provided a useful contrast to the UK, a long-time member of the European Communities. It would be difficult - if not impossible - to imagine a British ambassador or government spokeswoman today being willing or able to make such a statement. For successive UK governments, as well as the British public, 'Europe' has always appeared to involve a choice and therefore been the source of a persistent political dilemma. Since the idea of European integration gathered force in the 1950s, political actors in the UK have sought to resolve this tension within British political traditions (both domestic and international). This approach has tended to reinforce the political dilemma by emphasizing a Manichean choice for Britain between 'Europe' and 'the open sea'.

As such, voices in Britain could be heard asking if the wrong choice had been made in response to the dilemma posed by the country's part in the process of European integration. Writing from Melbourne in 2013, Boris Johnson spoke of the 'historic and strategic decision that this country took in 1973' in which 'we betrayed our relationships with Commonwealth countries such as Australia and New Zealand' (Johnson, 2013). This betrayal was the product of specific historical circumstances - domestic, European and global - that no longer pertained. Johnson argued that:

When Britain joined the Common Market, it was at a time when the establishment was defeatist, declinist and obsessed with the idea that we were being left out of the most powerful economic club in the world. In those days - when olive oil and garlic had barely appeared on the dining tables of Britain - it was assumed that in order to be internationalist' it was enough to be European. Well, it is perfectly obvious, in 2013, that that is no longer enough - and that we need to seek a wider destiny for our country. (Johnson, 2013)

So what seemed expansive in 1973 could be presented as parochial forty years later.

The Mayor of London was not alone in reaching this conclusion. Writing in The Spectator, James Forsyth argued that the rise of those he called the 'New Colonials' such as Mark Carney, Lynton Crosby, Ryan Coetzee and Andy Flower, in British public life was 'a reminder that we are part of a broader English-speaking world' - a fact that 'will become more and more important as the country debates what terms of EU membership are acceptable' (Forsyth, 2013). Conservative MEP Daniel Hannan promoted the idea of the Anglosphere in tours of Ireland, the United States, Canada, Australia and New Zealand 
between 2012 and 2014. These trips confirmed for him that 'the Anglosphere isn't fanciful or romantic or passé [rather] most English-speaking peoples know, almost without thinking about it, what they share' (Hannan, 2012). The attraction of such arguments is that they appear to make historic and cultural sense within an understanding of British history that emphasized global trading links rather than Europe alone.

Although these ideas might seem like mere cultural mood music or simply politeness towards one's hosts, there were two significant dimensions to their recent deployment: first, these ideas were finding support among conservatives in other English-speaking countries; and second, they were seemingly emerging as policy choices within British government. This renewed emphasis on longstanding and stable (if somewhat taken-forgranted) political relations chimed with calls for a political reorientation away from Europe. An increasingly vocal strand of opinion on the right of British politics and across the English-speaking world regarded the Anglosphere as a 'natural' and 'organic' political community to which greater political attention should be devoted (Sheridan, 2007). Speaking in Sydney only days before David Cameron's landmark speech on the EU in London, William Hague argued for closer political co-operation between Britain and Australia, exemplified by the ongoing 'five eyes' intelligence co-operation, the regular ministerial-level meetings inaugurated in 2006 under the name of AUKMIN, and diplomatic and consular co-operation in emerging countries (Hague, 2013).

The belief in the 'English-speaking people' as an extant, if loose, political community and the beginnings of a policy re-engagement with Commonwealth countries bring what we might call a 'Commonwealth tradition' back into British engagement with European integration. In other words, although in a very different global politics, we once again need to account for the Commonwealth and the English-speaking world in seeking to explain British policy and attitudes towards the EU. On one level, this is to be expected: according to Bevir et al., an actor's conceptualization of an issue will be framed by political traditions. 'A tradition,' they argue, 'captures this historical inheritance against the background of which individuals act' (Bevir et al., 2013, p. 167). This is not meant to be deterministic, but rather creates a situation that can be described as one of 'situated agency' (Bevir and Rhodes, 2003, 2006). Thus a tradition 'is unavoidable only as a starting point, not as something that determines later performances' (Bevir et al., 2013, p. 167).

What is interesting and important when viewing the recent support for the Anglosphere through this conceptual lens is that the tradition is slightly more determinative than the above account allows: history and tradition do not solely operate as the intellectual point of departure for an alternative vision to Britain's involvement in European integration. Instead, history and tradition are promoted as the point of destination, a solution to the dilemma generated by Britain's membership of the EU, a return to a more 'natural', 'organic' and less insular political community, and one sanctified by the past, rather than challenged by it.

It should also be noted that this understanding of the past was an increasingly English, rather than British, phenomenon. Debates about the existence or otherwise of English nationalism, and if it did exist what form it might take, had been running for over a decade. For Krishan Kumar (2003), English nationalism had been inhibited by the operations of the British Empire, but it was now making a return of sorts. For Arthur Aughey (2009, p. 146), English nationalism was 'a mood, not a movement', whereas for Mike Kenny 
(2014), the English had attained a heightened sense of nationhood without this (yet) turning into nationalism. Although Gifford and Vines differed on the extent of populism within a politics of Eurosceptic Anglo-Britishness (Gifford, 2014; Vines 2014), links between a sense of English grievance, expressions of Euroscepticism and a particular understanding of Britain's past were emerging and being articulated with increasing coherence (Wellings, 2010, 2012).

The distribution of UK Independence Party (UKIP) votes in the 2014 elections to the European Parliament again showed that the electoral appeal of Euroscepticism to be strongest in England, particularly the south. This divergence had been developing for some years. Susan Condor and Jackie Abell revealed different public attitudes towards nation and empire circulating in Scotland and England, with a sense of Britishness situated ambivalently between the positive Scottish views of nation and negative views of empire and negative English attitudes towards both (Condor and Abell, 2006). Research by Chatham House showed that the public favoured greater co-operation with Englishspeaking countries over and above the EU (Knight et al., 2012). Furthermore, these surveys revealed a marked difference on European integration between the general public and what was referred to as 'opinion formers' (Knight et al., 2012). However, these surveys did not distinguish the nationalities of the respondents. In contrast, research published in 2013 by the Institute for Public Policy Research showed a strong correlation between identifying as English and having negative feelings towards the EU (Wyn Jones et al., 2013). As the English disengaged from Europe, they and the coalition government sought out allies that did not challenge a dominant British view of the past and its traditional allies.

\section{European Integration and the Anglo-British Past}

As Craig Parsons (2003, pp. 2-3) noted, 'historically active ideas' are - via their advocates - in contest with each other: some ideas prevail and can be preserved via institutions, whereas other ideas fail to dominate and recede, even if they perhaps do not entirely go away. This was the case with Britain's Commonwealth connections that retained a powerful nostalgic and political pull well beyond the reality of the Commonwealth as a political community itself (see Ludlow in this issue). Consequently, when Britain acceded to the EEC there appeared to be few other viable alternatives and no real political dilemma in taking membership, despite the contentiousness of this decision. From the 1940s to the 1960s memory of intra-European conflict remained a strong mobilizer in favour of European integration.

Of course, it was not impossible to draw the 'European' lesson from the period 1914 to 1945 in Britain. Many did so - most notably Winston Churchill, who spoke eloquently in the postwar years on the need for European unity (as a staging post on the road to world government). But Churchill was the 'Great Equivocator' on this issue, as Hugo Young (1998) illustrated. For Young, Churchill's engagement in the early arguments for European integration was that of 'a grandiloquent map-maker who wanted to dissolve the divisions between warring continental countries, but was rooted in a system that cast Britain as a facilitator, even a mere spectator, of the process' (Young, 1998, p. 17). Furthermore, Churchill always underscored the historic and beneficial alliance between Anglophones. Writing in the Preface to his four volume History of the English-Speaking 
Peoples, he noted that: 'There is a growing feeling that the English-speaking peoples might point a finger showing the way if things turn out right, and of course defend themselves, so far as any of us have that power, if things went wrong' (Churchill, 1956, pp. vii-viii).

However, when viewed through the prism of historically constituted knowledge, it has been all too easy for 'situated agents' concerned with Britain's involvement in European integration to construct Britain's place in Europe as illegitimate for two main reasons: the first is the memory of conflict with erstwhile European enemies; and the second is the uneasy compatibility between the institutional structures being created to build 'Europe' and British political traditions - notably the existence and operation of parliamentary sovereignty. The survival of such traditions could be understood, or presented retrospectively, as the reason for which both world wars - and particularly the Second - were fought. Victory in those two wars justified their continuance (see Daddow in this issue).

One of the notable effects of debates about European integration in Britain has been to sustain the notion of the historical continuity of English institutions and political traditions, a key element in English national narratives. Both John Major and Hugh Gaitskell invoked 'a thousand years of British history' when framing their arguments about Britain's place (or not) in Europe. Gaitskell, however, was closer to the personal memory of the conflicts and common sacrifice that appeared to bind Britain to its Commonwealth allies, stating in his famous speech rejecting British membership of the EEC that the Labour Party at least did not intend to forget Vimy Ridge and Gallipoli (cited in Healey, 1989, p. 211). At the same time, Lord Clive Baillieu, the chairman of Dunlop, spoke out in favour of Anglophone unity, arguing that in the two great conflicts between 1914 and 1945, 'the balance was tipped in our favour by the unique working partnership which continued throughout, between the people of the United States and the British Commonwealth'. ${ }^{1}$ Similarly, Enoch Powell understood the threat posed to parliamentary sovereignty by the supranational institutions of the European Communities, not solely from logical first principles, but as historically illegitimate, describing the idea that laws were generated by an elected parliament as 'the fact for which men have fought and died' as he put it May $1975 .^{2}$

During the 1970s opinion in favour of Britain joining the Common Market often highlighted the end of the Empire and the subsequent impossibility of returning to the past. The British arm of the European Movement argued in 1974 that 'rising world demand and shortages have put an end to cheap food from the Commonwealth or anywhere else'. ${ }^{3}$ Similarly, Britain in Europe (1975, p. 3) argued that if Britain left the European Communities 'we would not go back to the world as it was when we joined, still less to the old world of Britain's imperial heyday'. To reinforce this point, Australian Prime Minister Gough Whitlam was quoted as saying:

I do not wish to give any impression that the present Australian government sees any advantage for Australia, for Europe or for the world in Britain leaving the Community we regard European economic and political integration as one of the great historic forward movements of this century. (Britain in Europe, 1975, p. 3)

\footnotetext{
${ }^{1}$ National Archives of Australia, M2576/88.

${ }^{2}$ British Library of Political and Economic Sciences, SHORE/10/59, 'The Great Debate', BBC Radio 3.

${ }^{3}$ European Movement - British Council, 1974.
} 
Thus although the result of the referendum in 1975 was a near 2:1 vote in favour of remaining in the EEC, motivations other than European unity were strongly evident among voters. Polling for the anti-EEC National Referendum Campaign ahead of the June vote noted that the main reason for voting 'yes' was a negative one: that Britain had nowhere else to go. Having lost the Empire, the people of Britain were looking for a new role, but not with any notable conviction (Boase Massimi Pollitt Partnership, 1975, p. 13). In sum, sentimental ties to the Commonwealth (and the wider English-speaking world) had never really gone away, but did not seem a viable alternative to Europe in the mid-1970s.

Ten years after accession to the EEC, the basic attitude towards Europe remained the same. This was put down to a lack of media coverage of matters European; a lack of education in schools about the EEC; and - after 1979 - hostility toward the newly elected European Parliament. ${ }^{4}$ Withdrawal was no longer a vote winner and there was a general resignation to the pull of geography over ties of sentimentality; people felt that the "bogus exaggerations of the Heath campaign have been discounted and cynicism many now be giving way to grudging recognition of the facts of geographical life', but there was underlying support for the concept of Europe provided that it does not conflict too harshly with 'kith and kin'. ${ }^{5}$ This particular theme resonated strongly. Several survey respondents noted that a recent conflict had shown where Britain's true friends and allies lay. 'The half-hearted support we got from [EEC countries] in the Falklands conflict was an insult, especially when compared with our old, true friends in Australia and New Zealand' ${ }^{6}$ The link between the Commonwealth and whiteness persisted throughout the decade and beyond, as evidenced by the debate about British citizenship in the lead up to the handover of Hong Kong in 1997 (Cohen, 1994, pp. 78-80).

By the 1990s, this sense of separate spheres for Britain, Europe and the Commonwealth was part of the accepted political wisdom. Speaking about the UK-Australia relationship in 1993, John Major remarked (like Harold Wilson before him) on the 'extraordinary - unparalleled - richness of personal and family ties between Britain and Australia' (Major, 1993, p. 89). But beyond this, Major reflected on the perception that 'there has been a steady parting of the ways between Britain and Australia, and a weakening of, even a neglect of, the relationship', which he argued was 'true up to a point, but only up to a point' (Major, 1993, p. 91). This (partial) parting of the ways was brought about because each country was driven by the imperatives of geography, economic interest, social change and political vocation to give a new priority to its own region (Major, 1993, p. 91). Given this, Major thought that a new relationship had emerged, but it was one that rested on a mutual recognition of separateness and not one that envisioned any enhanced form of co-operation (unlike today). 'It is perfectly natural for two nations on opposite sides of the world,' argued Major, 'to develop distinctive characters, to carve out particular roles in their own regions, to pursue policies which promote their own economic interests. That is what Britain has been doing in Europe. Likewise, Australia in Asia' (Major, 1993, p. 92). But he sounded a note that signalled some of the changes to come: '[T]wo countries with distinctive roles, distinctive societies, each with its own

\footnotetext{
${ }^{4}$ Special Directive: EEC Special - Tenth Anniversary of British Entry into Europe, 1982. Mass-Observation Archive, Box 42.

${ }^{5}$ Mass-Observation Archive, Box 42.

${ }^{6}$ Mass-Observation Archive, Box 42.
} 
particular contribution to make to the world, but with a wide agenda for natural cooperation and a host of interests in common' (Major, 1993, p. 93).

Even as late as the 1990s, however, such 'natural' co-operation could not be assumed. From the Australian perspective, the post-imperial phase still remained unresolved. The Australia Act of 1986 further distanced Australia from Britain in the operative institutional sense, while the republic debate of the 1990s emphasized the extent of Australia's difference from Britain. Added to this was one of the contexts of the republican debate: Australia's relationship to the emerging economies and regional blocs of Asia. As Graham Dobell noted at the turn of the millennium, 'Australia has spent the years since World War Two unlearning the European vision of home; and since the end of the Vietnam war Australia has been acting on this change'; an elite policy re-think that he contrasted favourably with what he called the Tories 'Eurowar' in Britain (Dobell, 2000, p. 322). However, it was that 'Eurowar' which would inaugurate a re-emphasis on the Englishspeaking peoples in the form of a reinvigorated political community - the Anglosphere.

\section{Euroscepticism and the Anglosphere}

Speaking in the debate on the Maastricht Treaty in 1992, the Conservative Minister for Europe, Tristan Garel-Jones, posed the question that always caused some awkward silences among British Eurosceptics: 'Can the anti-federalists, the Euro-sceptics and little Englanders offer a positive alternative?' (cited in Congdon, 1992, p. 14). Although hardly a ringing endorsement of European integration, it was a valid question. Reflecting on this in The Spectator, Tim Congdon mooted a response: the English-speaking peoples or what was now being referred to as the 'Anglosphere' (Congdon, 1992, pp. 14-15). Here was a response to a dilemma that not only used historical consciousness and political tradition as its point of departure, but as its place of destination too.

Since the late 1990s, exponents of the 'Anglosphere' idea have argued that the Englishspeaking nations are distinguished by a set of institutions and characteristics that the other advanced nations of Europe and Asia lack: 'a common law tradition, respect for private property, continuous representative government, and a culture that nurtures civil society and entrepreneurial enterprise' (Bennett, 2004, p. 54). Such an organization has been variously titled the 'English-Speaking Union' (Conquest, 1999), the 'Anglosphere Association' (Conquest, 2000, 2005), the 'Anglosphere Network Commonwealth' (Bennett, 2004) or simply 'the Anglosphere' (Hitchens, 2007). All of these epithets effectively describe the same thing: in short, a mutual political association that variously includes the UK, the US, Canada, Australia, New Zealand, India, the English-speaking Caribbean islands and Singapore - all dedicated to free trade and greater military and security co-operation that could constitute 'a centre of hope in the world [. . . ] round which peace, cooperation and democracy can develop' (Conquest, 2005, p. 225).

The Anglosphere idea is, in essence, a proposal for an international organization that accommodates - and indeed celebrates - the history, culture and institutions that many hard Eurosceptics believe make Britain different from the Continent. As John Laughland (not himself a supporter of the idea) explained, the argument runs that the Anglosphere countries are 'united by an attachment to individualism, the rule of law [...] and the elevation of freedom' and 'the implication is that these values are not shared by the corporatist, socialist, corrupt and even authoritarian political cultures prevalent on the 
European continent, and of which the EU is itself an expression' (Laughland, 2008). In this regard, an Anglosphere organization would be, among other things, a monument to the British exceptionalism that anti-integrationists often cite as a reason for British withdrawal or disengagement from EU.

The Anglosphere idea has proven attractive to prominent British Eurosceptics and a number of high-profile Conservative politicians. Margaret Thatcher (1999), David Willetts (2009), John Redwood (2005), Daniel Hannan (2008, 2010a, b, 2013), David Davis (2001), Norman Lamont (2001), Liam Fox (2005), Bill Cash, Michael Howard and William Rees-Mogg (all cited in Bennett, 2004) have all written or spoken in support of increased co-operation across the Anglosphere. And though this group could not be said to be representative of the Conservative Party's official attitude toward European integration, it nevertheless contains individuals who exert, or have previously exerted, considerable influence within the party.

The notion of a prevailing unity or commonality between English-speaking peoples is not new (Gamble, 2003, pp. 83-107). The English Speaking Union, for example, was established in 1918 and ideas for the federation of the Empire pre-date that. ${ }^{7}$ The idea of a formal intergovernmental Anglosphere organization is, however, a distinct and relatively recent innovation. It is different from the existing British Commonwealth, most notably in its inclusion of the United States, but also in its exclusion of nations that, despite being former British colonies, are not predominantly English-speaking, or do not possess a full complement of the characteristics and institutions that set the mooted members of an Anglosphere association apart.

It is difficult to pinpoint the exact birthdate of the Anglosphere idea, but two Hudson Institute Conferences in 1999 and 2000 effectively announced the arrival of an Anglosphere organization as a new concept in international relations discourse, with prominent and influential backers (Vucetic, 2008, p. 2). These two conferences - the first in Washington, DC and the second in Berkshire - brought together 'the intellectual heart of British-American conservatism' (Lloyd, 2000a). Delegates included Margaret Thatcher, David Davis, Conrad Black, Francis Fukuyama, James C. Bennett, John O’Sullivan, Robert Conquest, Owen Harries and Kenneth Minogue. It was here, argues John Lloyd, (who attended as a sceptical observer for the New Statesman) that the vague notion of closer co-operation between kindred English-speaking nations, 'congealed into a movement' (Lloyd, 2000b). The proceedings of the conference were never published, but many of the attendees subsequently wrote books and articles urging a formal Anglosphere organization, which were in turn published or promoted in Conrad Black's and Rupert Murdoch's transatlantic stables of newspapers (Vucetic, 2008, p. 3). Recently, commentators from outside of the US and UK have tried to make the case for an Anglosphere organization. The January 2011 special edition of the New Criterion was entitled 'The Anglosphere and the Future of Liberty' and contained contributions from Canadian Mark Steyn, Australian Keith Windschuttle and Indian Madhav Das Nalapat (Steyn, 2011; Windschuttle, 2011; Nalapat, 2011).

Robert Conquest is credited with the first detailed outline of what an Anglosphere Association might look like and is regarded, alongside John O'Sullivan (a former adviser to Margaret Thatcher) and Conrad Black, as one of the chief progenitors of the Anglosphere

\footnotetext{
${ }^{7}$ «http://esu.org/about/».
} 
idea. In his 2000 book, Reflections on a Ravaged Century, Conquest argued that 'the political arrangements of the West are defective', that 'the European Union is not proving to be the factor of strength expected by some' and that 'the EU, the Commonwealth, the UN and GATT are all seen in their different ways as faded, exhausted and fallen from their original promise and inspiration' (Conquest, 2000, pp. 267-8). The answer to this state of affairs was 'a more fruitful unity' (Conquest, 2000, p. 267) between the Anglosphere nations - an idea that is developed further in Conquest's 2005 book Dragons of Expectation. He contended that the aim of the Anglosphere Association would be

to become a bastion in all parts of the world around which states sharing in any degree our aims of human liberty and progress, or needing support against our mutual enemies, may rally; and an exemplar of that world community which does not at present exist. (Conquest, 2005, pp. 224-5)

The Association would comprise a proportionally representative Consultative Council (the executive) and a larger Assembly that would include foreign affairs, military, economic, social affairs, and legal and constitutional committees (Conquest, 2005, pp. 2249). The President of the Association would be the President of the United States 'as the largest and most powerful member' (Conquest, 2005, pp. 229-30) and 'the Queen, as head of state of so many component nations [. . . ] should have some titular precedence, such as Queen of the Association' (Conquest, 2005, p. 230). As for the permanent staff, it should be as small as possible and, 'after the experience of the EU, every effort must be made [. . . ] to ensure not merely an absence of bureaucratic distortion but active work to prevent and combat the bureaucratic attitude' (Conquest, 2005, p. 229).

Conquest (2005, p. 222) acknowledged that his proposed Anglosphere Alliance was 'a work of cultural and political science fiction', but argued that it should not be dismissed from consideration merely because it is fanciful. His enthusiasm for an Anglosphere Association, 'after the EU monster has lumbered off, or been corralled' (Conquest, 2005, p. 222) is shared by many high-profile British Eurosceptics. Chief among them was Margaret Thatcher, who, in a speech to the English Speaking Union in 1999, unequivocally endorsed an earlier iteration of Conquest's Anglosphere idea, remarking that 'such an international alliance [. . . ] would redefine the political landscape' and, in the long term, transform 'politically backward areas [by] creating the conditions for a genuine world community' (Thatcher, 1999). 'Unlike the European Union,' argued Thatcher, 'an English-Speaking Union would be united by those deeper values - our common moral commitments to democracy and freedom tied together by our common language.' Indeed, she went so far as to argue that 'God separated Britain from mainland Europe, and it was for a purpose' (Thatcher, 1999).

\section{The Anglosphere and British Traditions}

The conviction that Britain was and is irrevocably different from Continental Europe is the shared intellectual foundation of a prominent strand of hard British Eurosceptic thought and its frequent corollary: Anglosphere enthusiasm. Hard Euroscepticism, as defined by Taggart and Szczerbiak (2008, pp. 7-8), is a 'principled opposition to the EU and European integration', observable in parties that advocate withdrawal of their constituencies from the EU or parties whose policies are 'tantamount to being opposed to the whole 
project of European integration as it is currently conceived'. It is these hard Eurosceptics that tend to object to EU membership on cultural and historical grounds, and many of the same who express enthusiasm for an Anglosphere alternative.

The strong sense of British difference from the Continent that animates many Eurosceptics and Anglosphere enthusiasts is firmly rooted in a particular understanding of Britain's past. John Redwood encapsulated the centrality of history to hard Eurosceptic thought in his 2005 manifesto Superpower Struggles:

Britain is at peace with its past in a way that many continental countries could never be. [...] We do not have to live down the shame that many French people feel regarding the events of 1940-44. We do not have to live [. . .] with the collective guilt that Germany feels about the Holocaust. [. . .] We do not wake up every morning like Italians to wonder who might be in government today and which government ministers might be charged with corruption tomorrow. (Redwood, 2005, p. 12)

Such a rendering of the past is redolent of the dominant British historiography of the nineteenth and early twentieth centuries, which uncritically celebrated Britain's military and imperial achievement and the collective exceptionalism of the English-speaking peoples. The histories of Arthur Bryant, George Macauley Trevelyan and A.J.P. Taylor and, of course, Churchill's History of the English Speaking Peoples 'took a vividly patriotic line on Britain's past' and were widely taught in British schools and sold in large numbers both popularly and among political elites (Daddow, 2006, pp. 322-4). Trevelyan, for example, characterized England as 'a country of unique flexibility and stability, that had only found its true destiny when it turned about from continental Europe' (cited in Deighton, 2002, p. 103). Churchill was less dismissive of Europe than Trevelyan, but was no less convinced of Britain's essential differentness from the Continent. In a 1930 Saturday Evening Post article he wrote: 'We have our own dream and our own task. We are with Europe, but not of it. We are linked, but not compromised. We are interested and associated, but not absorbed' (Churchill, 1930). This view continues to resonate today, finding frequent expression in the arguments of many hard British Eurosceptics (Redwood, 2005, pp. 72-4).

British exceptionalism is similarly prominent in the histories of other Anglophone countries. One of the most influential 'grand narratives' of British history is H.E. Marshall's children's book, Our Island Story, which venerates Britain and the British legacy in Australia, celebrating the fact that 'the people in the two islands are friends and brothers, and ties of love draw them together across the ocean waves' (Marshall, 2006 [1905], p. 637). It was these 'ties of love' that many feared might be severed when Britain acceded to the European Communities (Dewey, 2009, pp. 163-8). As Harold Wilson (1961) famously remarked during a parliamentary accession debate: '[W]e are not entitled to sell our friends and kinsmen down the river for a problematical and marginal advantage of selling washing machines in Dusseldorf'. Clement Attlee expressed similar sentiment in his seminal 'I Say Halt!' Sunday Express opinion piece. In his view, the Commonwealth was a 'characteristically British' family of nations, 'misunderstood by outsiders', which contrasted favourably with the alternative of 'Continentalism' that lacked a shared history or 'common way of life' (Attlee, 1963).

Due in no small part to the 'exceptionalist' tradition of British history to which Our Island Story belongs, the British connection constitutes an important aspect of national 
identity for many citizens of Anglophone countries in the present day. In a 2005 speech to the Oxford Union, Indian Prime Minister Manmohan Singh declared that:

Our judiciary, our legal system, our bureaucracy and our police are all great institutions, derived from British-Indian administration and they have served our country exceedingly well. [...] If there is one phenomenon on which the sun cannot set, it is the world of the English-speaking peoples, in which the people of Indian origin are the largest single component. (Singh, 2005)

A similar sentiment was expressed by Canadian commentator and avowed Eurosceptic, Mark Steyn, when he suggested that 'as a general rule you're better off for having been exposed to British rule than not' (Steyn, 2011, p. 1). Andrew Roberts, a contemporary exponent of the 'exceptionalist' school of British history, contended that:

It is emphatically not that the English-speaking peoples are inherently better or superior people that accounts for their success, but that they have perfected better systems of government, ones that have tended to increase representation and accountability while minimising jobbery, nepotism and corruption [. . . ] while some other peoples on the planet have remained mired in authoritarianism, totalitarianism and institutionalised larceny. (Roberts, 2006, p. 636)

Niall Ferguson advanced similar ideas and arguments in his popular history, Empire: How Britain Made the Modern World. He concluded that 'Anglophone economic and political liberalism remains the most alluring of the world's cultures' (Ferguson, 2004, p. 373), and that the enduring appeal of Anglophone culture was the legacy of the British Empire which

undeniably pioneered free trade, free capital movements and, with the abolition of slavery, free labour [...] invested immense sums in developing a global network of modern communications, [...] spread and enforced the rule of law over vast areas and, though it fought many small wars, maintained a global peace unmatched before or since. (Ferguson, 2004, p. 366)

In such arguments, the unique British inheritance that makes further integration into Europe undesirable to hard Eurosceptics is the very same inheritance that unites the Anglophone world, rendering deeper co-operation and closer association not only eminently possible but indeed highly desirable. In this way, Daniel Hannan argued that although the EU is seemingly underpinned by a common 'western' tradition, the reality is fundamentally different. 'The three precepts that define Western civilization - the rule of law, democratic government and individual liberty - are not equally valued across Europe,' he claimed. 'When they act collectively, the member-states of the EU are quite ready to subordinate all three to political imperatives' (Hannan, 2013, pp. 4-5). Not only did membership of the EU threaten the UK with subordination to this anti-democratic culture, but it was also part of a wider threat to Anglosphere values and humanity.

As the sun sets on the Anglosphere imperium, we understand with sudden clarity what it is that we stand to lose. [...] As a devolved network of allied nations, the Anglosphere might yet exert its benign pull on the rest of the century. Without that pull, the future looks greyer and colder. (Hannan, 2013, pp. 17-18)

Eurosceptics frequently opine that the EU's constituent nations are too culturally, historically and politically diverse for a widely or deeply held sense of common European 
citizenship to be cultivated successfully. In the view of many Eurosceptics, citizenship is something that must evolve organically and cannot be engendered by 'anodyne' statements of community ideals like the Copenhagen Criteria (Conquest, 2005, p. 225). The 'non-civic histories of many European nations' are also cause for Eurosceptic concern. By contrast, the Anglosphere idea is a 'natural grouping,' centred on a shared culture and history - 'going with the cultural grain rather than cutting across it' (Conquest, 2005, p. 270). Moreover, the American Anglosphere advocate, James C. Bennett, contends that in an increasingly networked age, culture is becoming more, not less, important. As geographical barriers are broken down by technological innovation 'differences in language, customs, legal systems, religions, and other significant values' come to the fore (Bennett, 2003-4, p. 24). Therefore, groups of nations with deep commonalities are likely to enjoy more fruitful interaction than groups of nations bound together first and foremost by geographical proximity (Bennett, 2003-4, p. 25).

In this way, with the 'special relationship' at its core, the Anglosphere's proponents contend it would constitute a more authentic and robust standard-bearer for Western values than the EU could ever hope to be. Whereas they view the EU as militarily insipid, an Anglosphere Association would be an economic and military powerhouse. A formal Anglosphere alliance is the best way, argued Redwood (2005, p. 54), for Britain to 'enjoy the military protection of US forces' and benefit from 'the undoubted commercial and technological dynamism of the US peoples'. In addition, Tim Congdon anticipates that an alliance of English-speaking peoples might one day include the rapid growth economies of Hong Kong, Singapore, the Philippines and India. Privileged access to these markets, he argues, would be a boon for the British economy. 'Europe is by comparison something of a sideshow' (Congdon, 1992, p. 15). Redwood, Conquest, Roberts, Davis and Steyn also believe that the current geopolitical climate is a compelling reason for Britain to throw in its lot with the Anglosphere. They argue that with the emergence of China as a far from benevolent world power and the continued threat of Islamic fundamentalism Britain should be nailing its colours to a much sturdier mast than the EU (Redwood, 2005, pp. 14-15). In their view, the peaceful spread of Western values through economic globalization, or the sort of soft power espoused by the EU, will not be enough to secure the future of the West.

A frequent complaint levelled at the EU by British Eurosceptics is the excessive bureaucracy of the organization and the impingement of 'ten million lines of EU law' on British sovereignty (Davis, 2001). Eurosceptics are regularly enraged by what they view as unnecessary, unelected and petty intervention by the European Commission into areas they believe should be the sole preserve of sovereign nations or the individual. As Conservative MP David Willetts argues, 'trying to build Europe by standardising everything from drinking water to wine bottles is a betrayal of the true source of its greatness' (Willetts, 2009, p. 58). By contrast, the Anglosphere Association would be a much looser union, at least in a juridical sense, and thereby pose little threat to British sovereignty.

Interest in the Anglosphere idea does not emanate solely from the UK, although its confluence with Euroscepticism makes it especially important there. The current Australian Prime Minister, Tony Abbott, is London-born, Oxford-educated, a monarchist and self-described 'incorrigible Anglophile' (Abbott, 2011). With this background, one might expect him to be an advocate of a formally constituted Anglosphere alliance, but he is cool on the idea. The reasons behind his reservations speak to the difficulties his fundamentally 
pragmatic creed of conservatism might have in creating and sustaining such a significant new international body. He is quick to invoke the Burkean instinct for an organic evolution of policy over radical institutional reform and feels the already strong sense of unity and commonality between Anglophone countries makes a 'juridical union' redundant (Abbott, 2011). Much of the co-operation envisaged by advocates of an Anglosphere association already occurs on a largely ad hoc and gradual basis via a web of bilateral relationships. As Greg Sheridan (2007) attests:

Everywhere I went in the US-Australia alliance, I found the Brits. [ . . ] Our special forces train with theirs, as we do with the Americans. Our troops on exchange with the Brits can deploy into military operations with them [...] something we also do with the Yanks. Australian liaison officers attend the most sensitive British intelligence meetings and vice versa, in arrangements of such intimacy that they are equalled only in our relationship with the US [...] this was really all happening without any overarching structure to inform the public or even to give top-level policy guidance. It was organic.

It was not until 2007 that the 'astonishing, continuing, political, military and intelligence closeness' between Australia and Britain which so impressed Sheridan was partly corralled under the more formal auspices of AUKMIN (the Australia-UK Ministerial Dialogue), having adopted the model of AUSMIN (the older Australia-US equivalent). ${ }^{8}$

Co-operation through AUKMIN and AUSMIN-type structures seems to be perfectly satisfactory to the current governments of Anglophone nations. Co-operation is likely to continue in this vein, Tony Abbott believes, primarily because

for the countries of the Anglosphere to join together in a more formal alliance structure than they have already, would look to the rest of the world a simultaneously defensive and aggressive posture and be contrary to the inherently open and outward-looking nature of the English-speaking peoples. (Abbott, 2011)

Similarly, Daniel Hannan stops short of advocating any formalization of existing ties. And beyond the 'actually existing' Anglosphere, there are tensions within the concept. First, in eschewing the type of institutional set up that characterizes the EU, the success of the Anglosphere appears to rest on the existence of a constellation of like-minded politicians in English-speaking countries. Anglosphere proponents can no doubt take heart at the governments of Stephen Harper and Tony Abbott in Ottawa and Canberra, but such alignments are ephemeral. Second, it will be hard to sell the Anglosphere as a substitute for the EU. Most external observers see Britain's role as a global player enhanced rather than inhibited by EU membership (German Council on Foreign Relations, 2014). Finally, while English-speaking peoples share much in common, there is also much in the legacy of Empire and Commonwealth that divides.

Ultimately, it may well be the case that even advocates of the Anglosphere Association are happy for it to remain just an idea; a gratifyingly provocative retort to the likes of Tristan Garel Jones. Even its fiercest exponents acknowledge that an Anglosphere Association is unlikely to be realized anytime soon (Conquest, 2005, p. 222). Yet the practicalities and prospects of the Anglosphere as a functional entity are not really the main

\footnotetext{
8 'British, Australian Foreign and Defence Ministers Hold AUKMIN Talks', The Australian, 18 January 2011. Available at: «http://www.theaustralian.com.au/news/breaking-news/british-australian-foreign-and-defence-ministers-hold-aukmin -talks/story-fn3dxity-1225990419923».
} 
point of interest here. Anglosphere enthusiasm is significant first and foremost for what it says about a certain strand of hard British Euroscepticism and its conception of Britain's and England's identity and place in the world.

\section{Conclusions}

This article has sought to understand and explain the rise of arguments in favour of the so-called 'Anglosphere' among Eurosceptics in the UK. It has tried to do so by explaining European integration as a policy dilemma addressed through strong traditions in British political thought. Placing this contemporary analysis in a historical context it is argued that political actors in the period of 1950s to 1990s did not face a dilemma as such since there was less of a political choice to be made, even if the decision itself produced much argumentation. European integration seemed like the only viable option at the time. Although the US alliance remained strong (if contentious), a changing Commonwealth meant that the idea of the 'English-speaking peoples' was something of a political fantasy, even if it was one that retained a powerful nostalgic pull in the 1960s. After the 1990s, however, it became possible to argue that a new global order was emerging and that the EU was entering a period of decline. In this context, Eurosceptics promoted the Anglosphere in response to criticism that they offered no constructive alternatives alongside their disdain for European integration.

This emerging Anglosphere dimension to British Euroscepticism crystallized an important trait that was already discernible: responses to the policy dilemma posed by Britain's increasingly sceptical attitude towards European integration reinforced the centrality of British national narratives set in opposition to European integration at the heart of an increasingly Eurosceptic Englishness. What was observable, therefore, was a response to a fundamental political dilemma that not only used historical consciousness and political tradition as its point of departure, but as its place of destination. As a result, articulations of British Euroscepticism remain attached to those same wider categories of belonging that pull the English further away from any deep support for European integration.

\section{Correspondence:}

Ben Wellings

School of Social Sciences

Faculty of Arts

Monash University

Clayton 3800

Australia

email: ben.wellings@monash.edu

\section{References}

Abbott, A. (2011) Interview with Helen Baxendale, Parliament House, Canberra, 20 March.

Attlee, C. (1963) 'I Say Halt!' Britain Must Not Become Merely a Part of Europe'. Sunday Express, 4 February.

Aughey, A. (2009) 'The Wager of Devolution and the Challenge to Britishness'. In Gamble, A. and Wight, T. (eds) Britishness: Perspectives on the British Question (Oxford: Wiley Blackwell). 
Bennett, J.C. (2003-4) 'Networking Nation-States: The Coming Info-National Order'. National Interest, Vol. 74, pp. 17-30.

Bennett, J.C. (2004) The Anglosphere Challenge: Why the English-Speaking Nations Will Lead the Way in the Twenty-First Century (Lanham, MD: Rowman \& Littlefield).

Bevir, M. and Rhodes, R. (2003) Interpreting British Governance (Abingdon: Routledge).

Bevir, M. and Rhodes, R. (2006) Governance Stories (Abingdon: Routledge).

Bevir, M., Daddow, O. and Hall, I. (2013) 'Introduction: Interpreting British Foreign Policy'. British Journal of Politics and International Relations, Vol. 15, No. 2, pp. 163-74.

Boase Massimi Pollitt Partnership (1975) 'Summary of Qualitative Research Findings on Attitudes and Beliefs towards the EEC'. Survey carried out for the National Referendum Campaign. In British Library of Political and Economic Sciences, SHORE/10/45 [EEC, 1974-5].

Britain in Europe (1975) Referendum on the European Community (Common Market): Why You Should Vote Yes (London: HMSO).

Churchill, W. (1930) 'Editorial'. Saturday Evening Post, 15 February.

Churchill, W. (1956) A History of the English Speaking Peoples (London: Cassell).

Cohen, R. (1994) Frontiers of Identity: The British and the Others (London: Longman).

Congdon, T. (1992) 'Home is Where Our Language is'. The Spectator, 5 September.

Condor, S. and Abell, J. (2006) 'Romantic Scotland, Tragic England, Ambiguous Britain: Constructions of "the Empire" in Post-Devolution National Accounting'. Nations and Nationalism, Vol. 13, No. 3, pp. 453-72.

Conquest, R. (1999) 'Towards an English Speaking Union'. National Interest, Vol. 57, pp. 64-70.

Conquest, R. (2000) Reflections on a Ravaged Century (New York: W.W. Norton).

Conquest, R. (2005) Dragons of Expectation: Reality and Delusion in the Course of History (New York: W.W. Norton).

Daddow, O. (2006) 'Euroscepticism and the Culture of the Discipline of History'. Review of International Studies, Vol. 32, pp. 309-28.

Davis, D. (2001) 'The Nation-State Gene'. Outlook, March-April. Available at: «http:// sagamoreinstitute.org/ao/index/magazine/id/Mar-April2001».

Deighton, A. (2002) 'The Past in the Present: British Imperial Memories and the European Question'. In Muller, J.-W. (ed.) Memory and Power in Post-War Europe: Studies in the Presence of the Past (Cambridge: Cambridge University Press).

Dewey Jr., R.F. (2009) British National Identity and Opposition to Membership of Europe, 196163: The Anti-Marketeers (Manchester: Manchester University Press).

Dobell, G. (2000) Australia Finds Home: The Choices and Chances of an Asia Pacific Journey (Sydney: ABC Books).

Ferguson, N. (2004) Empire: How Britain Made the Modern World (London: Penguin).

Forsyth, J. (2013) 'The New Colonials Can Raise Our Sights beyond the Channel'. The Spectator, 18 July. Available at: «http://blogs.spectator.co.uk/coffeehouse/2013/07/the-new-colonials-canraise-our-sights-beyond-the-channel/».

Fox, L. (2005) 'A Culture That Has Stood the Test of Time'. Daily Telegraph, 2 August.

Gamble, A. (2003) Between Europe and America: The Future of British Politics (Basingstoke: Palgrave Macmillan).

German Council on Foreign Relations (2014) 'Britain Outside Europe? Views on the Future of the UK and EU from Europe and Beyond'. Available at: «https://ip-journal.dgap.org/en/ip-journal/ topics/britain-outside-europe-introduction».

Gifford, C. (2014) 'The People against Europe: The Eurosceptic Challenge to the United Kingdom's Coalition Government'. JCMS Vol. 52, No. 3, pp. 512-28. 
Hague, W. (2013) 'Britain and Australia: Making the Most of Global Opportunity'. Fourth John Howard Lecture, Sydney, 17 January. Available at: «http://bartondeakin.com.au/briefs/ 2013_John_Howard_Lecture.html».

Hannan, D. (2008) 'The Borders of the Anglosphere?'. Daily Telegraph, 16 April. Available at: «http://blogs.telegraph.co.uk/news/danielhannan/3676521/The_borders_of_the _Anglosphere/».

Hannan, D. (2010a) 'India's Relationship with the Anglosphere Will Define the Twenty-First Century'. Daily Telegraph, 25 September. Available at: «http://blogs.telegraph.co.uk/news/ danielhannan/100055331/indias-relationship-with-the-anglosphere-will-define-the-twentyfirst-century/».

Hannan, D. (2010b) 'The Internet is Dragging Britain away from Europe and towards the Anglosphere'. Daily Telegraph, 20 August 2010. Available at: «http://blogs.telegraph.co.uk/ news/danielhannan/100051187/the-internet-is-gradually-reorienting-britain-away-from -europe-and-toward-the-anglosphere/».

Hannan, D. (2012) 'I'll Go to the Ends of the Earth to Argue against the EU'. Daily Telegraph, 6 June. Available at: «http://blogs.telegraph.co.uk/news/danielhannan/100162842/ill-go-to-theends-of-the-earth-to-make-the-case-against-the-eu/».

Hannan, D. (2013) Inventing Freedom: How the English-Speaking Peoples Made the Modern World (London: HarperCollins).

Healey, D. (1989) The Time of My Life (London: Penguin Books).

Hitchens, C. (2007) 'An Anglosphere Future'. City Journal, Autumn. Available at: «http:// www.city-journal.org/html/17_4_anglosphere.html».

Johnson, B. (2013) 'The Aussies are Just like Us, So Let's Stop Kicking Them Out'. Daily Telegraph, 24 August. Available at: «http://www.telegraph.co.uk/news/politics/10265619/TheAussies-are-just-like-us-so-lets-stop-kicking-them-out.html».

Kenny, M. (2014) The Politics of English Nationhood (Oxford: Oxford University Press).

Knight, J., Niblett, R. and Raines, T. (2012) Hard Choices Ahead: The Chatham House-YouGov Survey 2012 - British Attitudes towards the UK's International Priorities (London: Royal Institute for International Affairs).

Kumar, K. (2003) The Making of English National Identity (Cambridge: Cambridge University Press).

Lamont, N. (2001) 'Strengthening the Anglo-Saxon Economic Zone'. Outlook, March-April. Available at: «http://sagamoreinstitute.org/ao/index/magazine/id/Mar-April2001».

Laughland, J. (2008) 'Why the "Anglosphere" is No Alternative for the EU'. Brussels Journal, 1 February. Available at: «http://www.brusselsjournal.com/node/2821».

Lloyd, J. (2000a) 'The Anglosphere Project'. New Statesman, 13 March. Available at: «http:// www.newstatesman.com/200003130015».

Lloyd, J. (2000b) 'The Right Prepares for Cultural War'. New Statesman, 27 November. Available at: «http://www.newstatesman.com/200011270012».

Major, J. (1993) 'Australia and Britain: A Relationship which Matters'. Speech by the Prime Minister, the Right Honourable John Major MP to the Britain-Australia Society, 21 January. In Kooyman, M. and Beckingham, P. (eds) Australia and Britain: The Evolving Relationship (Monash: ANZ Centre for International Briefing).

Marshall, H.E. (2006 [1905]) Our Island Story: A History of England for Boys and Girls (Chapel Hill, NC: Yesterday's Classics).

Nalapat, M.D. (2011) 'India and the Anglosphere'. New Criterion, January. Available at: «http:// www.newcriterion.com/articles.cfm/India-the-Anglosphere-6755».

Parsons, C. (2003) A Certain Idea of Europe (Ithaca, NY: Cornell University Press). 
Redwood, J. (2005) Superpower Struggles: Mighty America, Faltering Europe, Rising Asia (Basingstoke: Palgrave Macmillan).

Roberts, A. (2006) A History of the English Speaking Peoples since 1900 (London: Weidenfeld \& Nicholson).

Sheridan, G. (2007) 'Beginning of More Beautiful Friendship'. The Australian, 27 December. Available at: «http://www.theaustralian.com.au/news/beginning-of-more-beautiful-friendship/ story-e6frg6v6-1111115194211».

Singh, M. (2005) 'Speech to the Oxford University Union', 8 July. Cited in Nalapat, M.D. (2011).

Steyn, M. (2011) 'Dependence Day'. New Criterion, January. Available at: «http:// www.newcriterion.com/articles.cfm/Dependence-Day-6753».

Taggart, P. and Szczerbiak, A. (2008) 'Opposing Europe? The Politics of Euroscepticism in Europe'. In Taggart, P. and Szczerbiak, A. (eds) Opposing Europe (Oxford: Oxford University Press).

Thatcher, M. (1999) 'The Language of Liberty'. Speech to the English-Speaking Union, New York, 7 December.

Vaudin d'Imecourt, L. (2011) 'EU is Not a Question of Choice, It is Our Destiny'. Europolitics Monthly, Vol. 252, p. 8.

Vines, E. (2014) 'Reframing English Nationalism and Euroscepticism: From Populism to the British Political Tradition'. British Politics, doi:10.1057/bp.2014.3.

Vucetic, S. (2008) 'The Anglosphere: A Genealogy of Identity in International Relations' (Doctoral dissertation, Ohio State University).

Wellings, B. (2010) 'Losing the Peace: Euroscepticism and the Foundations of Contemporary English Nationalism'. Nations and Nationalism, Vol. 16, No. 3, pp. 488-505.

Wellings, B. (2012) English Nationalism and Euroscepticism: Losing the Peace (Oxford: Peter Lang).

Willetts, D. (2009) 'England and Britain, Europe and the Anglosphere'. In Gamble, A. and Wright, T. (eds) Britishness: Perspectives on the Britishness Question (Oxford: Wiley Blackwell).

Wilson, H. (1961) Parliamentary Debates, Commons, 5 ${ }^{\text {th }}$ series, vol. 645, 3 August, col. 1665.

Windschuttle, K. (2011) 'English Law and the Spread of Civilisation'. New Criterion, January. Available at: «http://www.newcriterion.com/articles.cfm/English-law-the-spread-ofcivilization-6754».

Wyn Jones, R., Lodge, G., Jeffrey, C., Gottfried, G., Scully, R., Henderson, A. and Wincott, D. (2013) England and Its Two Unions: The Anatomy of a Nation and Its Discontents (London: Institute for Public Policy Research).

Young, H. (1998) This Blessed Plot: Britain and Europe from Churchill to Blair (Basingstoke: Palgrave Macmillan). 